\title{
CANX wt Allele
}

National Cancer Institute

\section{Source}

National Cancer Institute. CANX wt Allele. NCI Thesaurus. Code C112100.

Human CANX wild-type allele is located in the vicinity of $5 q 35$ and is approximately $53 \mathrm{~kb}$

in length. This allele, which encodes calnexin protein, is involved in both antigen presentation and protein folding. 